\title{
Active flagellates grazing on prokaryotes in high salinity waters of a solar saltern
}

\author{
Jong S. Park, Heejung Kim, Dong H. Choi, Byung C. Cho* \\ Molecular and Microbial Ecology Laboratory, School of Earth and Environmental Sciences and \\ Research Institute of Oceanography, Seoul National University, Seoul 151-742, South Korea
}

\begin{abstract}
Heterotrophic nanoflagellates (HNF) are known to be active grazers of prokaryotes and frequently major agents of prokaryotic mortality in various marine environments. However, studies on HNF occurrences and activities in high salinity $(>300 \%$ ) waters have shown contradictory results. Further, measurements of active HNF grazing on prokaryotes have not been reported in high salinity waters. Interestingly, in high salinity waters of a solar saltern located on the west coast of Korea, the flagellate grazing rates determined by uptake of fluorescently labeled prokaryotes (FLP) ranged from 1.4 to $13.0 \times 10^{8}$ cells $\mathrm{l}^{-1} \mathrm{~h}^{-1}$, turning over prokaryotes in 9 to $48 \mathrm{~d}$. The occurrences of active grazing in high salinity waters were further independently confirmed through an FLP disappearance approach. Prokaryotes in high salinity waters seemed to be strongly controlled by flagellates grazing in summer in the saltern. Naturally, high occurrences of flagellates $\left(7\right.$ to $28 \times 10^{6} \mathrm{HNF} \mathrm{l}^{-1}$ ) were observed in high salinity waters. The flagellates were 5 to $12 \mu \mathrm{m}$ in length, devoid of autofluorescence and actively ingested prokaryotes. In cultures maintained in the dark for 4 mo after field samples were diluted to contain a single HNF per culture tube, active flagellate growth continued to be observed. It seems that heterotrophic and extremely halophilic eukaryotic grazers actively ingest prokaryotes in high salinity waters.
\end{abstract}

KEY WORDS: Heterotrophic nanoflagellate - Grazing - Solar saltern · High salinity waters · Crystallizer

Resale or republication not permitted without written consent of the publisher

\section{INTRODUCTION}

Heterotrophic nanoflagellates (HNF) are known to be active grazers of prokaryotes and frequently major agents of prokaryotic mortality in various marine environments (Sherr et al. 1989, Vaqué et al. 1994, Cho et al. 2000, Pedrós-Alió et al. 2000a, Choi et al. 2003). However, studies on HNF in high salinity $(>300 \%$ ) waters have reported contradictory results. In high salinity waters of 2 solar salterns in Spain, HNF were either absent or occasionally appeared (ca. $3 \times 10^{4}$ HNF $\mathrm{ml}^{-1}$; Pedrós-Alió et al. 2000b) and HNF grazing on prokaryotes were inactive (Guixa-Boixareu et al. 1996, Pedrós-Alió et al. 2000b). However, in high salinity waters in a Western Australian hypersaline lagoon, 4 zooflagellates were observed frequently enough to be identified and appeared to be prokaryotic feeders
(Post et al. 1983). Presumably, high salinity waters from geographically different areas would have different species compositions of HNF.

On the other hand, it is well known that prokaryotic abundances are usually $>1$ order of magnitude higher in high salinity waters than those in coastal waters (GuixaBoixareu et al. 1996, Pedrós-Alió et al. 2000b). Thus, the high salinity waters could provide plenty of food prey for grazers if they did exist. Therefore, we were curious to examine whether HNF occurred in high salinity waters of a solar saltern geographically located far from Australia and Spain, and whether significant prokaryotic mortality due to grazers occurred in high salinity waters. In this study, we carried out 2 types of grazing experiments (fluorescently labeled prokaryote [FLP] uptake and FLP disappearance) in a solar saltern located on the west coast of Korea. 


\section{MATERIALS AND METHODS}

Study area and sample collection. The solar saltern located on the west coast of Korea at Seoshin $\left(37^{\circ} 09^{\prime}\right.$ $36^{\prime \prime} \mathrm{N}, 126^{\circ} 40^{\prime} 44^{\prime \prime} \mathrm{E}$ ) is composed of 72 salt pans (about $50000 \mathrm{~m}^{2}$ ), varying from $720 \mathrm{~m}^{2}$ for salinity $<150 \%$ o to $230 \mathrm{~m}^{2}$ for salinity $>150 \%$ o with an average depth of ca. $10 \mathrm{~cm}$. Subsurface waters with salinity $>300 \%$ were sampled from the saltern edges with $50 \mathrm{ml}$ sterile polypropylene tubes avoiding scums and debris, and collected into 21 polycarbonate bottles presoaked in $10 \%(\mathrm{v} / \mathrm{v}) \mathrm{HCl}$ and copiously rinsed with deionized water. Sampling was conducted on April 28, June 4 and August 24, 2001. Temperature was measured using a digital thermometer. Salinity in the solar saltern was measured by diluting saltern waters with distilled water to fall within the scale of a Temperature/Conductivity/Salinity Instrument (YSI 30, YSI, $\mathrm{OH})$.

Abundances of $\mathrm{HNF}$ and HNF grazing rates. Samples for measurements of HNF abundance were immediately fixed with alkaline Lugol's solution ( $0.5 \%$ final conc.) and borate-buffered formalin (3\% final conc.; Sherr et al. 1989, Rassoulzadegan 1991). DAPI-stained HNF collected on $0.4 \mu \mathrm{m}$ polycarbonate filters (25 $\mathrm{mm}$ in diameter) under a vacuum not exceeding $100 \mathrm{~mm} \mathrm{Hg}$ were enumerated at 1000× magnification with UV excitation using an epifluorescence microscope (Sherr et al. 1987). Varying volumes $(0.1$ to $0.5 \mathrm{ml})$ of seawater were filtered depending on cell abundance. At least 150 microscopic fields and a total of 20 to 40 nonpigmented flagellates were counted. During counting, the length of short and long axes of HNF was measured with eyepiece reticules and recorded for biovolume calcula-

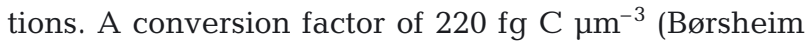
\& Bratbak 1987) was used to convert biovolume to cell biomass carbon. HNF grazing rates on prokaryotes were measured by using FLP prepared according to Sherr et al. (1987). Briefly, FLP were prepared by staining concentrated natural prokaryotic samples collected from the solar saltern 3 to $4 \mathrm{~d}$ before the fieldwork with 5-(4,6-dichlorotriazin-2-yl) aminofluorescein (DTAF), except in August when FLP prepared from June were used. In April, prokaryotes from $320 \%$ were used for the preparation of FLP by centrifuging $500 \mathrm{ml}$ of $33 \mu \mathrm{m}$ prefiltered seawater at $5000 \times g$ for $10 \mathrm{~min}$ to settle large particles. Supernatants were transferred to $50 \mathrm{ml}$ centrifuge tubes and centrifuged at $22000 \times g$ for 20 min to obtain pellets. In June, natural prokaryotes were concentrated to $200 \mathrm{ml}$ by hollow fiber ultrafiltration from $10 \mathrm{l}$ of $1.2 \mu \mathrm{m}$ prefiltered seawater (136\%) using filters of $0.1 \mu \mathrm{m}$ pore size, and then centrifuged at $22000 \times g$ for $20 \mathrm{~min}$ to obtain pellets. The pellets were resus- pended into $10 \mathrm{ml}$ of the PBS solution $(0.05 \mathrm{M}$ $\mathrm{Na}_{2} \mathrm{HPO}_{4}-0.85 \% \mathrm{NaCl}, \mathrm{pH}$ 9). Then, $2 \mathrm{mg}$ of DTAF was added and the cell suspensions were incubated at $60^{\circ} \mathrm{C}$ in a water bath for $2 \mathrm{~h}$. After incubation, the stained prokaryotes were centrifuged and washed 3 times with the PBS solution and subsequently suspended in a $0.02 \mathrm{M}$ tetrasodium pyrophosphate$0.85 \% \mathrm{NaCl}$ solution. The cell suspension was then sonicated with a tapered microtip (Model UP-400A, Sonicor Instrument) at $30 \mathrm{~W}$ to disperse large clumps. DTAF-stained prokaryotes were collected onto a $0.2 \mu \mathrm{m}$ polycarbonate black filter for enumeration via epifluorescence microscopy. Aliquots $(10 \mathrm{ml})$ were frozen at $-20^{\circ} \mathrm{C}$ in $20 \mathrm{ml}$ plastic vials. The FLP stocks ( 0.3 to $5.0 \mathrm{ml}$ ) were added to $250 \mathrm{ml}$ samples in polycarbonate bottles. The added concentration of FLP was between 0.6 and $14.9 \%$ of in situ prokaryotic abundance. A mean FLP biovolume was $0.103 \pm$ $0.05 \mu^{3}$ in April and $0.158 \pm 0.067 \mu \mathrm{m}^{3}$ in June. Prokaryotic abundance was measured by epifluorescence microscopy according to Porter \& Feig (1980). Briefly, prokaryotic samples were fixed with $0.2 \mu \mathrm{m}$ filtered, borate-buffered formalin ( $2 \%$ final conc.). Prokaryotes stained with DAPI and collected on a black $0.2 \mu \mathrm{m}$ polycarbonate filter were counted under UV excitation using an epifluorescence microscope. FLP-uptake experiments were carried out in duplicate in $250 \mathrm{ml}$ polycarbonate bottles presoaked in $10 \%(\mathrm{v} / \mathrm{v}) \mathrm{HCl}$ and copiously rinsed with deionized water. The experiments were conducted in the dark at in situ temperature. At 0, 10, 20 and $30 \mathrm{~min}, 30 \mathrm{ml}$ subsamples were collected, fixed and kept refrigerated until microscopic examination. Subsamples were DAPI-stained and filtered, and the filters were first observed under UV excitation at a magnification of 1000x. When a flagellate was located, the incident light was switched to blue and the numbers of FLP contained within the HNF were counted. We calculated the number of ingested FLP per grazer per hour (FLP uptake rate) from the slope of ingested FLP per grazer versus incubation time for each bottle. We calculated clearance rates (nl grazer ${ }^{-1} \mathrm{~h}^{-1}$ ), grazing rates on prokaryotes (cells $\mathrm{l}^{-1} \mathrm{~h}^{-1}$ ) and ingestion rates (cells grazer $^{-1} \mathrm{~h}^{-1}$ ) as in Park \& Cho (2002). The ranges of the coefficient of variation $(\mathrm{CV}=100 \times \mathrm{SD} / \mathrm{mean})$ of the slopes from duplicate bottles were 2.0 to $46.4 \%$ $($ mean \pm SD of $25.7 \pm 19.9 \%$ )

We also measured total grazing rates by the FLP disappearance according to Salat \& Marrasé (1994). From the high salinity waters, 21 of seawater were incubated at in situ temperature in duplicate. All incubation vessels were composed of polycarbonate bottles. To 21 polycarbonate bottles, 4.6 to $4.8 \mathrm{ml}$ of the prepared FLP stocks were added. After FLP were added to the bottles, subsamples of $50 \mathrm{ml}$ were taken immediately. 
Further subsamples of $50 \mathrm{ml}$ were taken after $48 \mathrm{~h}$ of incubation. Each sample was used to determine prokaryotic and FLP abundance. Because of difficulties in filtering enough high salinity water, additions of FLP to $50-250 \mathrm{ml}$ of $0.2 \mu \mathrm{m}$ filtered saltwater from a crystallizer were used to observe the losses of FLP that were unrelated to grazing. The initial concentration of FLP was between 1.7 and $12.4 \%$ of in situ prokaryotic abundance. The grazing rates and net instantaneous growth rates were calculated according to Salat \& Marrasé (1994), assuming that FLP and natural prokaryotes were removed at the same rate.

Growth of HNF from high salinity waters. To find out whether HNF grazing in high salinity waters could result in HNF multiplication despite the high salinity stress caused by high salinity environments, a water sample from a crystallizer $(310 \%$, May 31,2001$)$ was size-fractionated through $10 \mu \mathrm{m}$ Nitex $^{\circledR}$ and amended with an autoclaved barley grain. The filtrate was incubated in duplicate in the dark at $25^{\circ} \mathrm{C}$, and changes in prokaryotic and HNF abundances were monitored for 8 d. In accordance with Bloem \& Bär-Gilissen (1989), we calculated the doubling time and ingestion rate of HNF for an interval of HNF growth coinciding with a maximal decline of prokaryotes. Also, measurements of the growth rate of isolated HNF from high salinity waters were taken. To isolated HNF, the $10 \mu \mathrm{m}$ filtrate was amended with an autoclaved barley grain and kept in continuous darkness for $8 \mathrm{~d}$. Then, a subculture was transferred every $8 \mathrm{~d}$ to fresh medium $(0.2 \mu \mathrm{m}$ filtered, autoclaved saltwater of $310 \%$ and amended with the grain) and kept in darkness. After transfer 5 times, the culture was diluted with fresh medium to a probability of $1 \mathrm{HNF}$ per 2 to 5 culture tubes. Growth of HNF in each tube was confirmed through the observation of increases in HNF abundance. The isolation step was further repeated 2 times over the next 5 mo. The finally established culture was incubated at $22 \pm 1^{\circ} \mathrm{C}$ without shaking and monitored for HNF and prokaryotic abundance. To obtain fast growth of the isolated $\mathrm{HNF}$, the culture was amended with $1 \%(\mathrm{w} / \mathrm{v})$ of yeast extract and/or heat-killed prokaryotes (final conc. of $1.1 \times 10^{8}$ cells ml ${ }^{-1}$ ).

Photographs of HNF. Microscopic observations and image acquisitions were performed on the Olympus Model BX60 microscope system. Live HNF from cultures as well as live HNF and fixed HNF from a solar saltern were observed by phase-contrast and epifluorescence microscopy, respectively. All samples were from high salinity waters of a solar saltern. Digital images were captured with a CoolSNAP-Pro digital camera (Media Cybernetics), controlled by Image Pro Plus software (Media Cybernetics). Images were further processed for display using Image Pro Plus software.
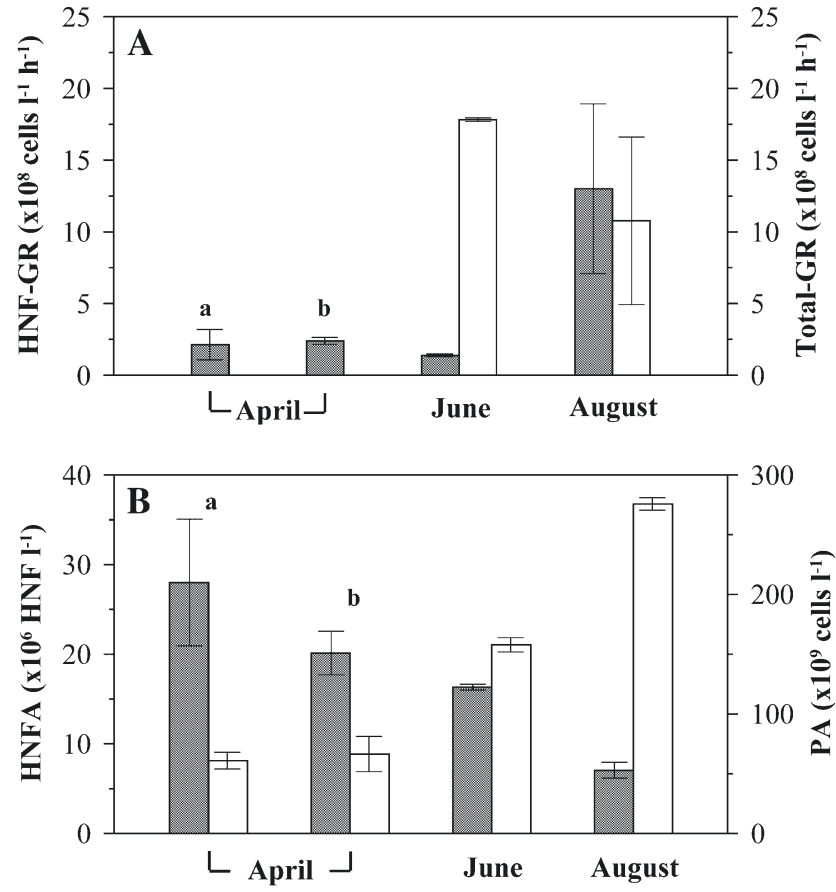

Fig. 1. (A) Grazing rates (GR, shaded bars) of prokaryotes by heterotrophic nanoflagellates (HNF) and total grazing rates (empty bars), and (B) HNF abundance (HNFA, shaded bars) and prokaryotes (PA, empty bars) in high salinity waters in April, June and August. Water temperature was 17.6 and $20.6^{\circ} \mathrm{C}$ in April at a salt pan of $318 \%$ (a) and $376 \%$ (b), respectively; it was $27^{\circ} \mathrm{C}$ at a salt pan of $343 \%$ in June and $34^{\circ} \mathrm{C}$ at a salt pan of $310 \%$ in August. Error bars $=1 \mathrm{SD}$

\section{RESULTS AND DISCUSSION}

Interestingly, initial experiments of FLP uptake performed in April showed that prokaryotes were actively grazed in high salinity waters at rates of 2.1 to $2.4 \times 10^{8}$ cells $\mathrm{l}^{-1} \mathrm{~h}^{-1}$ (Fig. 1A). Therefore, to find out whether grazing on prokaryotes occurred in high salinity waters and also who participated in grazing, FLP uptake experiments were suitable. The grazers of prokaryotes were microscopically discovered to be HNF. HNF observed in high salinity waters were small (5 to $12 \mu \mathrm{m}$ long), devoid of red autofluorescence (Fig. 2) and abundant ( 7 to $28 \times 10^{6} \mathrm{HNF} \mathrm{l}^{-1}$; Fig. 1B). Some HNF seemed to be morphologically similar to Phyllomitus sp. and Bodo sp. observed in a Western Australian hypersaline lagoon (Post et al. 1983). To independently confirm the observation of active grazing in high salinity waters, total grazing experiments by observing disappearance of FLP were also subsequently carried out. In June, the HNF grazing rate on

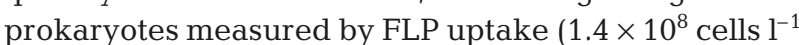
$\mathrm{h}^{-1}$ ) was much lower than the total grazing rate of 17.8 $\times 10^{8}$ cells $^{-1} \mathrm{~h}^{-1}$ (Fig. 1A). In August, the HNF grazing rate on prokaryotes $\left(13.0 \times 10^{8}\right.$ cells $\left.^{-1} \mathrm{~h}^{-1}\right)$ was similar 

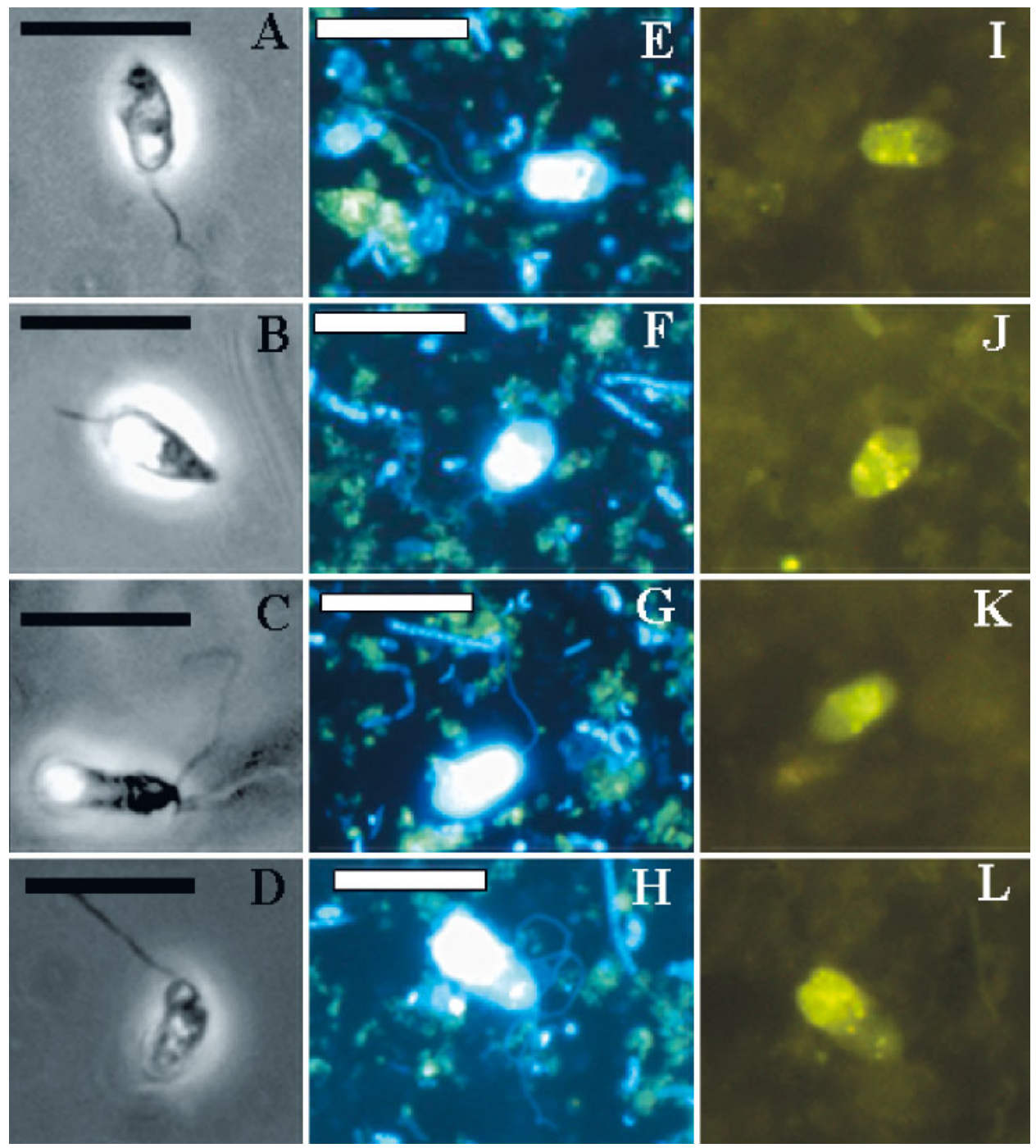

Fig. 2. (A-C) Phase-contrast photomicrographs of the live heterotrophic nanoflagellates (HNF) from a solar saltern and (D) cultures. (E-H) Epifluorescence photomicrographs of fixed HNF visualized under a UV-filter set, and (I-L) those of the corresponding HNF which ingested fluorescently labeled prokaryotes visualized under a blue filter set. All samples were from high salinity waters of a solar saltern and examined at $\times 1250$. Scale bars $=10 \mu \mathrm{m}$

to the total grazing rate of $10.8 \times 10^{8}$ cells $\mathrm{l}^{-1} \mathrm{~h}^{-1}$ (Fig. 1A). FLP uptake and FLP disappearance experiments would not necessarily give similar estimates of grazing rates due to the different incubation times in the 2 approaches (Sakka et al. 2000). In this study, due to difficulties of filtering enough high salinity waters in the field, sample volumes of control were much less than those of treatments. However, losses of FLP during the incubation were insignificant in control bottles (data not shown). In September 2002, we further carried out an additional FLP disappearance experiment in the laboratory in which the same water volume (2 l) was used for both treatment ( $324 \%$ saltwater) and control $(0.2 \mu \mathrm{m}$ filtered saltwater) bottles (data not shown).
A total grazing rate of $13.7 \pm 2.7 \times 10^{8}$ cells $\mathrm{l}^{-1} \mathrm{~h}^{-1}$ was obtained, comparable to that measured in August 2001. Thus, our results from the FLP disappearance experiments in 2001 seem to be acceptable. Based on the 2 types of grazing assays, we could clearly demonstrate that active grazing on prokaryotes occurred in high salinity waters. Since ciliates were not observed in high salinity waters of our study site (J. K. Choi pers. comm.), HNF would be responsible for the total grazing in our samples.

Furthermore, the growth of HNF in $10 \mu \mathrm{m}$ filtrate of high salinity water was observed (Fig. 3A). According to Bloem \& Bär-Gilissen (1989), the growth and ingestion rates of HNF were estimated to be $0.015 \mathrm{~h}^{-1}$ (i.e. 
$1.9 \mathrm{~d}$ of doubling time) and 168 cells $\mathrm{HNF}^{-1} \mathrm{~h}^{-1}$, respectively. Using an estimated value of $21 \mathrm{pg} C$ for HNF carbon biomass and $20 \mathrm{fg} \mathrm{C}$ for prokaryotic carbon biomass (Lee \& Fuhrman 1987), we could illustrate that HNF grazing on prokaryotes was enough to support the observed HNF growth in high salinity water. Thus, it seemed that HNF in high salinity water samples were not necessarily mere survivors of the hypersaline condition, but could actively graze on prokaryotes and multiply. Further, a successful culture of an isolated HNF was established in our laboratory and the cultured HNF had a doubling time of $1.1 \mathrm{~d}$ (Fig. 3B). Additionally, the HNF culture could have been maintained in the dark for more than a year, indicating that the isolated HNF would be a heterotrophic prokaryotic grazer.

During the study, HNF abundance was highest $(28 \times$ $10^{6} \mathrm{HNF} \mathrm{l}^{-1}$ ) in April. Prokaryotic abundance, not including square-shaped archaea, was maximum in

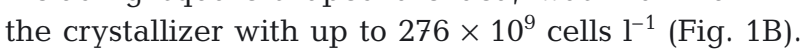
The observed HNF grazing rates in high salinity water samples (Fig. 1A) could turnover prokaryotes within $12 \mathrm{~d}$ (April), $48 \mathrm{~d}$ (June) and $9 \mathrm{~d}$ (August), and correspond to $25 \%$ (April), $85 \%$ (June) and 358\% (August) of prokaryotic production as determined by ${ }^{3} \mathrm{H}$-thymidine (unpubl. data). Thus, HNF strongly seemed to control prokaryotes in high salinity waters in August. The high HNF grazing pressures on prokaryotes in summer were apparently due to increases in temperature and prokaryotic abundance.

Active grazing and abundant occurrences of HNF in high salinity waters raise the question of whether the HNF in high salinity waters adapt to field conditions. Calculations of HNF growth rates in August were based on the measured ingestion rate of 181 cells $\mathrm{HNF}^{-1} \mathrm{~h}^{-1}$ along with a HNF biomass carbon of $24.9 \mathrm{pg}$ $\mathrm{C} \mathrm{HNF}^{-1}$ and a prokaryotic biomass carbon of $24.9 \mathrm{fg} \mathrm{C}$ $\mathrm{cell}^{-1}$. With a gross growth efficiency of $10 \%$ (calculated from $10 \mu \mathrm{m}$ filtrate culture, see above), the observed ingestion rate of HNF could support a $2.3 \mathrm{~d}$ doubling time of HNF growth. Although this estimate is slightly slower than doubling times observed in cultures, it indicates that HNF in high salinity waters seem to adapt well to their environment. However, for samples collected in April and June, estimated HNF ingestion rates of prokaryotes were on average $9.3 \pm$ 2.4 cells $\mathrm{HNF}^{-1} \mathrm{~h}^{-1}$. The similar calculations of the HNF growth rate suggest that the HNF grew slowly (i.e. doubling time of $24.0 \pm 8.6 \mathrm{~d}$ ), presumably reflecting worse conditions for them during those months. Possibly, HNF were also able to utilize other food sources. For example, HNF in high salinity waters might ingest viruses as other HNF do (González \& Suttle 1993), since viral abundance was so high $\left(10^{12}\right.$ viruses $\mathrm{l}^{-1}$; unpubl. data) in high salinity waters. In addition, dur-
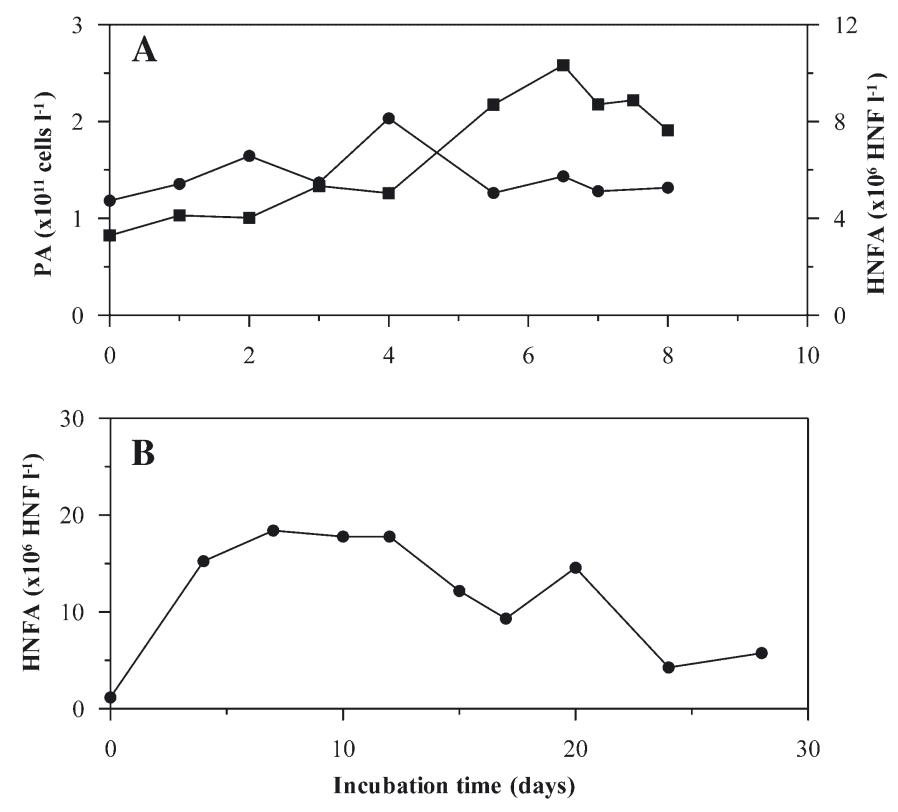

Fig. 3. (A) Changes of prokaryotic abundance (PA, $\bullet$ ) and heterotrophic nanoflagellate abundance (HNFA, $\mathbf{\square})$ in $10 \mu \mathrm{m}$ filtrate in the dark. On May 31, 2001, a water sample from the crystallizer $(310 \%)$ was size-fractionated through $10 \mu \mathrm{m}$ Nitex ${ }^{\circledR}$, amended with an autoclaved barley grain and incubated in duplicate in the dark. (B) Changes of HNFA in a culture of an isolated HNF from high salinity water in the dark

ing microscopic examinations, we often observed that HNF ingested DAPI-stained yellow particles (data not shown) probably rich in protein (Mostajir et al. 1995).

The growth of HNF in both filtrate and culture suggests that HNF could heterotrophically grow in high salinity waters and that these HNF could be extremely halophilic, eukaryotic grazers of prokaryotes. Although phytoplankton in high salinity waters might not be limited by nutrients (Joint et al. 2002), we could not exclude the possibility that the HNF in high salinity water samples might be also mixotrophic flagellates closely related to photosynthetic Dunaliella species. Volcani (1944) observed that a green flagellate similar to Dunaliella viridis, a common inhabitant of the Dead Sea, completely lost its green color when grown in a semi-solid agar medium in the dark. Occurrences of Dunaliella species were observed in our samples of high salinity waters (Yang 2002). Further research is needed to determine the nutritional mode of HNF in high salinity waters.

In an ecological sense, our observations of active flagellates grazing in high salinity waters would provide a simple explanation for recently observed rapid ammonium turnover in a crystallizer (Joint et al. 2002). Their result implies a considerable recycling activity of ammonium in high salinity waters to balance the demand. Since grazing activities of microzooplankton 
and protozoa are the major agents of ammonium regeneration in seawaters (Harrison 1978, Glibert 1982), and microzooplankton herbivory was not observed in a crystallizer (Joint et al. 2002), protozoan bacterivory would be a plausible mechanism for ammonium regeneration. That is, HNF bacterivory in a crystallizer could be a main cause of the considerable recycling activity of ammonium.

Finally, since salterns use seawater which has the same major constituents of salts all over the world, it is believed that these ecosystems are markedly similar too, and thus the conclusions drawn from the study of specific salterns should have a general validity (Oren 1994). In this respect, our observation of the presence of prokaryotic grazers in high salinity waters would be interesting because the previous work in salterns in Spain (Guixa-Boixareu et al. 1996, Pedrós-Alió et al. $2000 b$ ) did not observe grazing on prokaryotes by flagellates in high salinity waters. The question is then, how could it be possible for us to find the active flagellates grazing in high salinity waters of solar salterns? This disparity does not seem to be due to methodological problems because previous studies as well as ours used standard methods for measuring protozoan grazing rates. Considering that 4 species of prokaryotic feeding zooflagellates were also observed in a Western Australian hypersaline lagoon (Post et al. 1983), in all likelihood species of HNF might be different between our study site and those in Spain. In support of our idea, eukaryal assemblages were recently reported to be more diverse in high salinity waters than previously thought (Casamayor et al. 2002).

To summarize, in high salinity waters with very high prokaryotic abundance, there were active prokaryotic grazers exploiting the plentiful food prey. Also, flagellates were able to survive in high salinity waters and they strongly controlled prokaryotes in summer. Further research is now needed to determine the phylogenetic identification and nutritional mode of HNF, mixotrophy or heterotrophy.

Acknowledgements. We thank Mr. W. Y. Lee for permission to sample the salterns at Seoshin. The present study was supported by the Korea Sea Grant Program (B.C.C.) and Project BK 21 of the Korean government.

\section{LITERATURE CITED}

Bloem J, Bär-Gilissen MJB (1989) Bacterial activity and protozoan potential in a stratified lake. Limnol Oceanogr 34: 297-309

Børsheim KY, Bratbak G (1987) Cell volume to cell carbon conversion factors for a bacterivorous Monas sp. enriched from seawaters. Mar Ecol Prog Ser 36:171-175

Casamayor EO, Massana R, Benlloch S, Øvreås L and 6 others (2002) Changes in archaeal, bacterial and eukaryal assemblages along a salinity gradient by comparison of genetic fingerprinting methods in a multipond solar saltern. Environ Microbiol 4:338-348

Cho BC, Na SC, Choi DH (2000) Active ingestion of fluorescently labeled bacteria by mesopelagic heterotrophic nanoflagellates in the East Sea, Korea. Mar Ecol Prog Ser 206:23-32

Choi DH, Hwang CY, Cho BC (2003) Comparison of virusand bacterivory-induced bacterial mortality in the eutrophic Masan Bay, Korea. Aquat Microb Ecol 30: 117-125

Glibert PM (1982) Regional studies of daily, seasonal and size fraction variability in ammonium remineralization. Mar Biol 70:209-222

González JM, Suttle CA (1993) Grazing by marine nanoflagellates on virus and virus-sized particles: ingestion and digestion. Mar Ecol Prog Ser 94:1-10

Guixa-Boixareu N, Calderón-Paz JI, Heldal M, Bratbak G, Pedrós-Alió C (1996) Viral lysis and bacterivory as prokaryotic loss factors along a salinity gradient. Aquat Microb Ecol 11:215-227

Harrison WG (1978) Experimental measurements of nitrogen remineralization in coastal waters. Limnol Oceanogr 23: $684-694$

Joint I, Henriksen P, Garde K, Riemann B (2002) Primary production, nutrient assimilation and microzooplankton grazing along a hypersaline gradient. FEMS Microbiol Ecol 39: $245-257$

Lee S, Fuhrman JA (1987) Relationships between biovolume and biomass of naturally derived marine bacterioplankton. Appl Environ Microbiol 53:1298-1303

Mostajir B, Dolan JR, Rassoulzadegan F (1995) A simple method for the quantification of a class of labile marine pico- and nano-sized detritus: DAPI yellow particles (DYP). Aquat Microb Ecol 9:259-266

Oren A (1994) The ecology of the extremely halophilic archaea. FEMS Microbiol Rev 13:415-440

Park JS, Cho BC (2002) Active heterotrophic nanoflagellates in the hypoxic water-column of the eutrophic Masan Bay, Korea. Mar Ecol Prog Ser 230:35-45

Pedrós-Alió C, Calderón-Paz JI, Gasol JM (2000a) Comparative analysis shows that bacterivory, not viral lysis, controls the abundance of heterotrophic prokaryotic plankton. FEMS Microbiol Ecol 32:157-165

Pedrós-Alió C, Calderón-Paz JI, MacLean MH, Medina G, Marrasé C, Gasol JM, Guixa-Boixareu N (2000b) The microbial food web along salinity gradients. FEMS Microbiol Ecol 32:143-155

Porter KG, Feig YS (1980) The use of DAPI for identifying and counting aquatic microflora. Limnol Oceanogr 25: 943-948

Post FJ, Borowitzka LJ, Borowitzka MA, Mackay B, Moulton $\mathrm{T}$ (1983) The protozoa of a Western Australian hypersaline lagoon. Hydrobiology 105:95-113

Rassoulzadegan F (1991) Methods for the study of marine microzooplankton. In: Reid PC, Turley CM, Burkill PH (eds) Protozoa and their role in marine processes. Springer Verlag, Berlin, p 39-57

Sakka A, Legendre L, Gosselin M, Delesalle B (2000) Structure of the oligotrophic planktonic food web under low grazing of heterotrophic bacteria: Takapoto Atoll, French Polynesia. Mar Ecol Prog Ser 197:1-17

Salat J, Marrasé C (1994) Exponential and linear estimations of grazing on bacteria: effects of changes in the proportion of marked cells. Mar Ecol Prog Ser 104:205-209

Sherr BF, Sherr EB, Fallon RD (1987) Use of monodispersed, fluorescently labeled bacteria to estimate in situ protozoan 
bacterivory. Appl Environ Microbiol 53:958-965

Sherr BF, Sherr EB, Pedrós-Alió C (1989) Simultaneous measurement of bacterioplankton production and protozoan bacterivory in estuarine water. Mar Ecol Prog Ser 54: 209-219

Vaqué D, Gasol JM, Marrasé C (1994) Grazing rates on bacteria: the significance of methodology and ecological factors. Mar Ecol Prog Ser 109:263-274

Editorial responsibility: Fereidoun Rassoulzadegan, Villefranche-sur-Mer, France
Volcani B (1944) The microorganisms of the Dead Sea. In: Papers collected to commemorate the 70th anniversary of Dr. Chaim Weizmann. Daniel Sieff Research Institute, Rehovoth, p 71-85

Yang DJ (2002) A comparative study on the variation of phytoplankton distribution and primary productivity at the southern SaeManKeum area and the Soo-sung saltern. MSc thesis, Seoul National University

Submitted: December 16, 2002; Accepted: June 3, 2003

Proofs received from author(s): August 21, 2003 